\title{
ONLINE LANGUAGE TEACHING AND LEARNING: ANGLISTICS STUDENTS' PERSPECTIVES ON THE NEW EDUCATIONAL ENVIRONMENT IMPOSED BY THE COVID 19 OUTBREAK
}

ABSTRACT. This paper focuses on students' perspectives on the quality of online teaching and learning environment, created, and organized as a response to the COVID-19 outbreak, which unexpectedly interrupted the traditional face-to-face education context and changed the delivery and mode of classes overnight. The aim of this research is to gather information pertaining to students' learning experience in an online education environment, and to gain a deeper insight into the nature of online delivery of classes as perceived by students who had not had any similar learning experience prior to this newly created educational context. The theoretical framework of the paper states the latest EU education policies passed as an immediate and urgent response to the pandemic and its aftermath. This pilot study relies on a qualitative research which includes the analysis of a corpus of questionnaires taken by a group of 52 undergraduate students majoring in English. The main part of the questionnaire is composed of open-ended questions, and the respondents were asked to write their own answers, thus

mprodanovic@singidunum.ac.rs

vgavranovic@singidunum.ac.rs

This paper was submitted on August $18^{\text {th }}, 2020$ and accepted for publication at the meeting of the Editorial Board held on September $25^{\text {th }}, 2020$. 
providing a valuable resource for the analysis; the other part relies on one Likert-scale question measuring the overall attitude of the respondents to the online learning. The students' answers are analyzed and classified into several categories according to their common denominator. Not only do the results show the students' opinions related to the benefits and drawbacks of online delivery of classes, the comparison of online and traditional form of teaching and learning, types of courses which are more suitable to be delivered in one of these modes, and the students' suggestions how to improve the quality of online classes, but they also shed light on different aspects of online teaching and its complexities enhanced by social and psychological factors involved.

KEYWORDS: online language learning environment; COVID-19 pandemic; students' perspectives.

\section{INTRODUCTION}

The academic year 2019/2020 was suddenly disrupted by the outbreak of the COVID-19 pandemic, and educational institutions responded to this newly created situation in different ways, with varying degrees of success and commitment. Never before has the importance of conducting some kind of online teaching and learning been so obvious and justifiable, and educational systems worldwide underwent considerable changes overnight switching to online education environment.

The COVID-19 pandemic has not only accelerated the introduction of ICT into the area of education at a brisk pace over the previous months, but also led to the most dramatic changes in the education system the modern era has witnessed. The pandemic has emptied classrooms around the globe, stopped the teaching-learning flow teachers and students were used to, and made all the stakeholders within education process reach out for new teaching approaches, methods, and techniques, with the goal of completing the academic year. It has been estimated that around 100 million students, as well as teachers has introduced a plentiful number of novelties into their everyday lives and routines-the novelties they were only reading about several months ago. ${ }^{3}$

As the predictions concerning the status of the ongoing pandemic over the coming months and its strong influence on everyday life

3 https://ec.europa.eu/education/news/public-consultation-new-digital-educa tion-action-plan_en 
do not eliminate the possibility of introducing some lasting changes in the sphere of education, the EU Commission (June 2020) announced the Guidelines addressing the potential education forms we all might be experiencing during the 2020/2021 academic year. ${ }^{4}$

One of the primary goals of the mentioned document, issued by the EC, is to shed some more light on the phenomenon and possibilities of blended learning, and to point to the new roles and expectations of all the stakeholders in the process; though it appears that the changes are almost inevitable, the paramount need for keeping, and even improving, the quality of education, as well as for preserving the iconic-social and nurturing role of school, is at the forefront of all the contemporary thoughts and recommendations.

In response to the new teaching and learning environment, UNESCO also gave its voice to prioritization of education continuity, and organized the Global Education Coalition, the goal of which is a strong support of remote education and help for all the participants of the process. ${ }^{5}$

In a similar vein, OECD issued a report on education response to the COVID-19 pandemic- addressing the importance of challenges which might appear along the path of remote education implementation. The report illustrated a survey which gathered the respondents from as many as 98 countries around the globe and their responses to the unprecedented disruption we have witnessed. Furthermore, it pointed out the most salient points to be considered e.g., education continuity, assessment integrity, graduation policies, teachers' and learners' wellbeing, computer literacy, curricular priorities, etc. At the same time, the respondents' reminiscences of the previous period (from the moment the crisis affected us on) revealed that they found it difficult to find the right balance between online and offline activities, students' emotional health, technological infrastructure, etc. ${ }^{6}$

The main aim of this study is to gather information pertaining to students' perspectives and attitudes towards the quality and characteristics of online language teaching and learning environment, and to gain a deeper insight into students' learning experience

4 https://www.schooleducationgateway.eu/downloads/Blended\%20learning\%2 0in\%20school\%20education_European\%20Commission_June\%202020.pdf

5 https://unesdoc.unesco.org/ark:/48223/pf0000373348

6 https://read.oecd-ilibrary.org/view/?ref=126_126988-t63lxosohs\&title=A-fra mework-to-guide-an-education-response-to-the-Covid-19-Pandemic-of-2020 
related to this period. The purpose of this research is to identify advantages and potential problems of online learning as perceived by the students with the aim to gain a deeper insight into different aspects of online language teaching and learning.

\section{THE REDEFINED ROLE OF TECHNOLOGY IN EDUCATION}

Integrating technology into teaching-learning processes, at different levels, rests on the foundations of a number of EU recommendations; however, a lack of or inadequate equipment, IT infrastructure, support, and needed computer literacy skills are obstacles on the path of such integration. Furthermore, it is not enough to simply add technological infrastructure and thus make some courses, programmes, trainings and other educational forms online; "innovations may require more" (Torrisi-Steele and Drew, 2013, as cited in Castro, 2019, p. 2531), which, definitely, would include pedagogical transformations and redesign of syllabi and curricula used at institutions around the world. The rich body of MOOC (massive open online courses) platforms, along with OER (open education resources) databases could be seen as facilitators and factors which could pave the way for more effective utilization of online instructions at different levels of education, but it appears that, prior to the pandemic outbreak, they had not reached their full potential; moreover, not long ago, back in 2015, the reports showed that $58.7 \%$ of higher education institutions in the USA did not plan to introduce any MOOCs in the foreseeable future (Allen et al., 2016, p. 6), as they believed that the issues of accessibility, costs and legitimacy were yet to be addressed.

In this respect, it is worth noting that blended learning is not regarded as a new phenomenon anymore; institutions have been relying on its potential for decades, and its implementation has been supported by a number of sources, aimed to assist both experienced teachers and novices, embarking on the usage of technology in their classrooms (one of the most influential being the one by Sharma \& Berrett, 2007). Its primary characteristic is a simultaneous combination of face-to-face and online instruction - over the previous decades, blended learning proved to be successful and applied in courses in a number of countries around the globe (e.g., 
China, Canada, Russia, Australia, Germany, the UK, etc. Hockly, 2018, p. 98). A report from 2016 stated that around 5.8 million students in the USA were exposed to online teaching and learning methods (Yen et al., 2018, p. 2142).

Then again, despite the fact that much happened over the course of several years in the ICT field - and the fact that deploying online platforms and tools does require time, investments, as well as adequate support for all the participants (Castro, 2019, p. 2542), it seems that we have all recently become dependent on ICT-without any proper preparation. The unstoppable changes taking place in the field of technology constantly remind us of the need to update ourselves on the recent trends and needs.

Given the fact that the Covid-19 pandemic is an ongoing era-we are still making continuous and strenuous effort to familiarize ourselves with all its traits and draw some lessons we can rely on in the future. Undisputedly, the experiences and challenges students and teachers have undergone in the meantime are yet to be discussed in the future, but the voices illustrating the issue at the moment agree that the educational environment we currently live in has significantly altered our roles (Huang et al., 2020), which, as such, ask for an activation of creativity on the part of all the participants in the process $^{7}$. In addition, the research evidence in the area, though scarce and dominantly characterized by a plethora of guidelines, is pointing to careful attention we should pay to assessment, teacher presence, and design in online learning (Rapanta et. al., 2020, pp. 22-23), as well as the fact that professionals coming from different spheres of human endeavor should join forces (Jandrić, 2020, p. 234) in overcoming the challenges we have been exposed to.

\section{THE CONTEXT AND METHODOLOGY OF THE RESEARCH}

What educators and students faced at the beginning of spring 2020 was a mere leap into the unknown-and left no space for blending. During the winter portion of the academic year, all the respondents participating in this research were engaged in traditional, face-to-face teaching. At the beginning of the summer term (the very end of February 2020), they managed to attend traditional,

7 Further reading: Ferdig et al., 2020 
classroom-held lectures for two weeks - when the pandemic outbreak resulted in the closure of educational institutions. Student satisfaction and comparison between two forms of instructionface-to-face and online was measured via Student Opinion Questionnaire (SOQ), administered to a group of 52 students, aged 19-26, all four years, studying the English language and literature at the University of Singidunum in Belgrade. Language students were chosen to participate in this study because language learning is grounded in social interaction (Hellerman, 2008, p. 2), which is challenged by the online learning environment because it is not the same as face-to-face classroom (Hoffman 2010, p. 100). The respondents anonymously gave their answers to a set of questions, which were delivered online, administered through the Google Forms app, and the goal of which was to compare and contrast two learning environments they had previously familiarized themselves with.

Although being very skillful at using ICT, the students had not been engaged in online learning modalities prior to the closure of classrooms, a mere "educational experiment" $(\mathrm{Pu}, 2020$, p. 3) we faced in March. On a positive note, all the participants in the process, i.e., both teachers and students proved to be very responsive when it comes to the major change of direction for education on a global scale. Apart from using a learning platform (course management system, CMS) for the distribution of PPTs, illustrating lecture notes, and handouts, which has been a part of the university practices for years, in the new virtual learning environment (VLE), students and teachers primarily relied on an online communication platform, which enabled them to bridge the gap - prior to traditional classrooms reopening.

The questionnaire the respondents took consists of two sets of questions. The first set comprises five open-ended questions devised with the aim to explore students' opinions and perceptions related to online learning, its advantages and disadvantages, how they perceive online learning environment compared to a traditional delivery of classes in a classroom, and suggestions how to improve the quality of online lessons. The main reason why the researchers opted for open-ended questions was to motivate students to think critically and reflect upon their own learning experience, using their own thoughts and ideas expressed with their own choices of unrestricted, unlimited words, not previously predetermined by the examiners. Questions devised in such a way also pre- 
vent the occurrence of a potential risk of students being influenced by the choice of words representing examiners' knowledge and preconceived ideas of the characteristics of online teaching and learning and its various aspects. More importantly, the answers to these questions have the potential to cast some new light on the nature of the issue of online leaning and illuminate it better, helping teachers obtain a deeper insight in the complexities of teaching and learning, which is even more amplified by various changes affecting society in a more general context.

The answers to these open-ended questions are analyzed inductively and categorized, and in certain instances subsequently subcategorized, into groups sharing some common denominator. Some questions had clearly defined categories, such as stating advantages and drawbacks, or giving preference to one form of teaching context, while some categories described in the analysis of the students' answers were formulated by the researches based on the characteristics of the answers-expressing positive or negative attitude, cognitive, affective, or social aspect of learning. These categories and subcategories of answers are represented in tables (Table 1-5), and the findings subsequently discussed, providing the research topic with a varying layers of concern.

Another part of the research relies on the Likert-scale question measuring the overall attitude of the respondents to the online learning, and it comprises the question "Online teaching and learning has met my expectations". Although the question was broadly formulated, its aim was to inquire the affective aspect of students' perception. In order to ensure a midpoint and thus make it easier for students to come to a more objective answer, we opted for a 5 -point scale, 1 being the most favorable, and 5 the least desirable experience.

The number of open-ended questions is limited to 5 because the researchers expected the students to have sufficient focus span to provide thorough and comprehensive answers indicative and resourceful for a qualitative and conclusive discussion. The main findings of the research primarily rely on the analysis of the answers to the open-ended questions, and the only close-ended question supplements these quantitative data gathered from the first set of questions with an overall attitude summarized in simple terms, which can serve as some form of conclusion. The comparison of the results reinterprets the data and provides a better 
understanding of students' needs and attitudes towards online learning context.

\section{RESEARCH RESULTS AND ANALYSIS}

The first open-ended question asked the students to reflect upon their online experience during the last three months of the academic year 2019/2020, and to describe the quality of the online lectures they had attended using the most appropriate and precise adjective(-s) they would attribute to them. The average number of adjectives the students wrote in the questionnaire amounts to three, and according to their semantic features, the adjectives the respondents used could be classified into categories which share a common denominator referring to the quality of the classes in general, students' feelings, accessibility and innovation. Table 1 shows these categories and the examples provided by the students, arranged from the most frequently used, with the number in brackets denoting how many times they occur in the answers.

\begin{tabular}{|c|c|}
\hline CATEGORY & ADJECTIVES THE RESPONDENTS USED \\
\hline $\begin{array}{l}\text { ADJECTIVES REFERRING } \\
\text { TO THE QUALITY OF } \\
\text { CLASSES IN GENERAL (75) }\end{array}$ & $\begin{array}{l}\text { efficient (16), engaging (8), motivating (6), concise (5), dynamic (5), } \\
\text { well organised (4), professional (4), excellent (4), focused (3), timely } \\
\text { (3), clear (3), great (3), demanding (2), extremely productive (2), } \\
\text { amazing (2), brilliant (1), wonderful (1), superb (1), tedious (1), dif- } \\
\text { ficult (1) }\end{array}$ \\
\hline $\begin{array}{l}\text { ADJECTIVES REFLECTING } \\
\text { STUDENTS' FEELINGS/ } \\
\text { INTERESTS IN THE } \\
\text { CLASSES (34) }\end{array}$ & interesting (16), fun (10), enjoyable (7), boring (1) \\
\hline $\begin{array}{l}\text { ADJECTIVES DENOTING } \\
\text { ACCESSIBILITY }(20)\end{array}$ & accessible (12), convenient (8) \\
\hline $\begin{array}{l}\text { ADJECTIVES DENOTING } \\
\text { INNOVATION (19) }\end{array}$ & $\begin{array}{l}\text { innovative (6), modern (5), contemporary (3), advanced (2), cool } \\
\text { (1), unique (1), eye-opening (1) }\end{array}$ \\
\hline
\end{tabular}

TABLE 1: ADJECTIVES THE RESPONDENTS USED TO DESCRIBE THE QUALITY OF ONLINE LECTURES ( ПРИДЕВИ КОЈЕ СУ ИСПИТАНИЦИ КОРИСТИЛИ ЗА ОПИС ОНЛАЈН НАСТАВЕ)

The second question asked the students to write about the benefits and risks of online lectures; their answers are summarized in 
the Table 2, and the number in brackets denotes how many students wrote similar answers, formulated in different sentences, but having the same propositional value.

\begin{tabular}{|c|c|}
\hline & 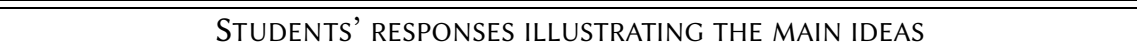 \\
\hline BENEFITS & $\begin{array}{l}\text { - It saves my time. I don't waste time on public transport. (37) } \\
\text { - The lectures are easily accessible. (28) } \\
\text { - I can listen to some more problematic parts of the lecture once again, or if I } \\
\text { missed the class, I can go through the lecture on my own. (20) } \\
\text { - We can be more productive. (5) } \\
\text { - We can improve our IT skills. (3) } \\
\text { - As an employed student, I can either participate in an online lecture, or } \\
\text { watch the recorded material later. (3) } \\
\text { - We can improve our self-discipline and self-control. (2) } \\
\text { - We can study and participate regardless of our place of living. (2) } \\
\text { - It is safe, especially nowadays, during the pandemic. (2) } \\
\text { - We can improve our online communication and collaboration. (2) } \\
\text { - I can drink coffee or have some other refreshment (it helps me concentrate). } \\
\text { I am also more relaxed, and I'd say more enthusiastic to study and to partici- } \\
\text { pate in lectures. (1) }\end{array}$ \\
\hline $\begin{array}{c}\text { DRAWBACKS } \\
/+ \text { ČĐ } \\
\text { POTENTIAL } \\
\text { RISKS }\end{array}$ & $\begin{array}{l}\text { - Less interaction (14) } \\
\text { - A lack of attention. It was difficult to maintain attention all the time. (7) } \\
\text { - A lack of face to face communication (5) } \\
\text { - The problems with the Internet connection (4) } \\
\text { - A lack of peer interaction (4) } \\
\text { - Not immediate response (I felt uncomfortable to ask something online), so it } \\
\text { happened at times that I needed clarification and misunderstood some parts of } \\
\text { the lecture. (1) }\end{array}$ \\
\hline
\end{tabular}

TABLE 2: STUDENTS' RESPONSES RELATED TO THE BENEFITS/ DRAWBACKS OF ONLINE LECTURES (ОДГОВОРИ СТУДЕНАТА У ВЕЗИ СА ПОЗИТИВНИМ И НЕГАТИВНИМ СТРАНАМА ОНЛАЈН НАСТАВЕ)

Having evaluated online lectures with the key words (adjectives), and through a more thorough reflection upon the advantages and problems they faced in their own online learning experience, the students were asked, in the third question, to compare traditional, face-to-face with online lectures. The analysis of the answers shows there are three general sentiments present among the respondents: $15 \%$ of the students give advantage to online lectures over tradition delivery of classes, half of them still prefer traditional to online lectures, while almost 35\% do not prioritize any of these and consider both as valuable modes of delivery, seeing no essential difference in terms of the content delivery and the quality of lectures, 
but rather perceive difference resulting from the very conditions wherein the lectures are given. The Table 3 shows the commonest answers the students wrote, classified into these three categories, and the arguments for their preferences; the number in brackets refers to the number of students who used a similar answer/ argument, with the same propositional value, only formulated in different words.

\begin{tabular}{|c|c|}
\hline CATEGORY & STUDENTS' ANSWERS ILLUSTRATING THE CATEGORY \\
\hline $\begin{array}{l}\text { THE SAME } \\
\text { STATUS (18) }\end{array}$ & $\begin{array}{l}\text { - For me everything is the same, except that we are not together in the class- } \\
\text { room, but still we get to learn and ask everything that we are not sure about. }\end{array}$ \\
\hline $\begin{array}{l}\text { TRADITION } \\
\text { AL OVER } \\
\text { ONLINE } \\
\text { LECTURES } \\
(26)\end{array}$ & $\begin{array}{l}\text { - Traditional classroom learning is more interactive. } \\
\text { - In my opinion, traditional learning is always the most favourable and effective } \\
\text { method of learning. However, online learning is a wonderful alternative. } \\
\text { - I believe that non-verbal communication is as important as verbal communi- } \\
\text { cation. } \\
\text { - Traditional is better when it comes to communication and especially body lan- } \\
\text { guage, understanding every uttered word, being able to make friends, and to } \\
\text { study together. } \\
\text { - a less personal experience in online. } \\
\text { - When online things move at a faster pace whereas in the classroom we have a } \\
\text { little more time to think and do work. } \\
\text { - In traditional classroom learning, students feel more natural to participate } \\
\text { and express themselves/ traditional classes are more suitable for the real life. } \\
\text { - I find it really hard to concentrate during the lectures and to find motivation } \\
\text { and energy to do what is expected of me, like homework. I've gotten really lazy. } \\
\text { - feel more at ease to speak up in the classroom then during the online lecture. }\end{array}$ \\
\hline $\begin{array}{c}\text { ONLINE } \\
\text { OVER } \\
\text { TRADITIONA } \\
\text { L LECTURES } \\
\quad(8)\end{array}$ & $\begin{array}{l}\text { - Regarding online classes, I would probably take notes on my laptop when in } \\
\text { classroom I can get easily distracted. } \\
\text { - As a shy person, I would like to point out that I have been more active during } \\
\text { online lectures. } \\
\text { - This has a positive influence on my concentration since I am unable to hear } \\
\text { background noise and students who are unwilling to participate cannot be } \\
\text { heard when chatting to their friend. } \\
\text { - Online classes give me more time to myself as I do not waste time on transport. } \\
\text { - Online learning keeps us accountable. In traditional classroom learning we } \\
\text { may get tired of all day classes and have smaller attention span. }\end{array}$ \\
\hline
\end{tabular}

TABLE 3: STUDENTS' RESPONSES TO THE COMPARISON OF ONLINE AND TRADITIONAL LECTURES (ОДГОВОРИ СТУДЕНАТА У ВЕЗИ СА ПОРЕБЕЊЕМ ТРАДИЦИОНАЛНЕ И ОНЛАЈН НАСТАВЕ)

Since all the respondents are undergraduate students majoring in English, with much experience related to learning all language 
skills, literature and linguistically oriented courses, they were asked, in the fourth question, to evaluate which courses are more suitable for traditional delivery and which courses would students gain from more when organized online. A number of students replied that the online lectures provide a more effective environment for the development of any language skill or learning any subject matter, but none of them explicitly stated the name of the course, they just expressed this general opinion with no example or argument to support their stance. The majority of students (75\%) explicitly replied that both traditional and online lectures are effective for language learning; anyhow, some of them added that for some courses, traditional learning environment could be more suitable. The Table 4 shows which courses appear in the answers, and the number of students who wrote them. The main reason which supported their opinion, if stated in the answers, was the lack of face-to-face communication (referring to language skills), or the complexity of the subject matter per se.

\begin{tabular}{|c|c|}
\hline $\begin{array}{c}\text { COURSES FOCUSING ON } \\
\text { LANGUAGE SKILLS - GENERAL }\end{array}$ & AlL LANGUAGE SKILLS (12) \\
\hline $\begin{array}{c}\text { LANGUAGE SKILLS - } \\
\text { PRODUCTIVE SKILLS }\end{array}$ & SPEAKING SKILLS (10), TRANSLATION (9) WRITING SKILLS (6) \\
\hline
\end{tabular}

TABLE 4: STUDENTS' RESPONSES TO THE QUESTION WHICH COURSES COULD BE MORE EFFECTIVE IN TRADITIONAL CLASSROOM ENVIRONMENT

(ОДГОВОРИ СТУЕНАТА НА ПИТАҢЕ О ПРЕДМЕТИМА ЧИЈА РЕАЛИЗАЦИЈА МОЖЕ БИТИ ЕФИКАСНИЈА У ТРАДИЦИОНАЛНОМ ОКРУЖЕЊУ)

The last question asked the students to come up with their own ideas and thoughts on successful online teaching, and to write down which criteria should be met in order to accomplish it. This question was done by almost $60 \%$ of the respondents, while the rest of them either left the blank space or wrote 'I wouldn't change anything' or 'Everything was fine', providing no specific suggestion.

The analysis of the answers shows that the students were concerned with two main aspects of teaching - the quality of the delivered content and class management on the one hand, and the use of ICT on the other, and their answers were classified accordingly. These categories are shown in the Table 5, with the examples for each criterion and the number of students who gave similar answers. 


\begin{tabular}{||c|l||}
\hline CRITERION & Students' responses illustrating the criterion \\
\hline THE QUALITY OF & - well-prepared, well-organised, good time management \\
THE LECTURE & - engaging for all students \\
(CONTENT, & - well-established both teacher-student and student-student interaction \\
MANAGEMENT, & - creative, useful, comprehensive, interesting \\
DELIVERY) (12) & - clear instructions \\
\hline A HIGH & - additional learning material \\
STANDARD OF & - a variety of educational applications \\
TECHNICAL & - a good quality of PPT presentations \\
SUPPORT (18) & - user-friendly software \\
\hline \hline
\end{tabular}

TABLE 5: STUDENTS' RESPONSES RELATED TO CRITERIA FOR A SUCCESSFUL ONLINE LEARNING ENVIRONMENT (ОДГОВОРИ СТУДЕНАТА У ВЕЗИ СА КРИТЕРИЈУМИМА ЗА УСПЕШНО ИЗВОЪЕњЕ ОНЛАЈН НАСТАВЕ)

The last question was devised to assess the respondents' attitudes towards online teaching and learning environment based on their own three-month experience, and it was given in a form of a closed-ended Likert 5-point scale question. The results are presented in the Chart 1.

\section{DISCUSSION}

Although the scope of the questionnaire is limited to six questions, and the number of the respondents represents a small group appropriate for a pilot study, the analysis of the answers the respondents wrote yields some consistent patterns which are repetitive throughout the entire corpus, highlighting some important aspects related to the students' attitudes towards the nature of online lectures. Furthermore, the open-ended questions opened the unrestricted space for some answers which cast light on various aspects of teaching, analyzed below.

The commonest adjectives the respondents used to describe the quality of the online lectures they had attended for three months indicate how important time management and efficiency, as well as personal feelings attached to learning experience are for the $21^{\text {st }}$ century students. Prioritizing innovation in teaching also emerges as an important factor for the students, because almost $40 \%$ of the 
respondents used some adjective containing the semantic feature 'new, novelty'.

Other questions from the questionnaire also contribute to creating a better insight into what students expect from not only online classes but also from traditionally organized lessons. The answers to the question related to benefits of online learning to a great extent coincide with the adjectives the students provided to describe the quality of online lectures. More than $70 \%$ of the students stated that the most beneficial aspect of online teaching relates to time saving, and more than half of the respondents stated that online teaching provides accessibility as an advantageous characteristic. This argument is in compliance with the strategy of EU education policies, which emphasize lifelong learning and mobility as the main objectives to be pursued. The answers provided in this section of the questionnaire also illuminate some important aspects which should be taken into consideration, and these refer to safety, the possibility to develop crucial $21^{\text {st }}$ century skills and literacies - digital literacy, IT skills, online communication and collaboration, creativity and critical thinking skills.

A social aspect of learning appeared as an important factor with over a half of the respondents, who replied that the main disadvantage of online learning lies in the lack of interaction, either between the teacher and the students or among students themselves, and face-to-face communication was emphasized as a relevant form of interaction. Another drawback stated in the responses refers to a difficulty experienced by almost $14 \%$ of the students to maintain attention during a lecture. These results are in compliance with the EU Commission analytical report, illustrating the influence of technology on students' empathy, as well as their attention capacity (Flecha et al., 2020). The report points out that context, along with content selection, undoubtedly affects the mentioned phenomena, but that empathy is more prominent on occasions when the chosen activities are of prosocial nature, i.e., rooted in the principles of a dialogue.

The comparison of traditional and online learning, and the examples and arguments given by the students to support their opinions at the same time confirm, but also deepen and clarify many statements already made in the previous three questions. Namely, those who gave advantage to online learning emphasize accessibility, efficiency and time saving as the key beneficial characteristics, while, on the other hand, those who prefer traditional 
to online learning point out the importance of social aspect of education and interaction. However, this question yielded some answers which illuminate the issue better and provide a deeper insight into the complexities of teaching and learning, no matter in what context they are carried out. In the first place, psychological aspect of learning arises as a relevant factor, and shows that interaction for some students, particularly the introverts, is better realized in an online environment, which helps them express themselves freely and be more active in classes. Another aspect perceived differently is attention - for some students, traditional classroom face-to-face environment is distracting, and they manage to maintain concentration when these classes are delivered online, while others can focus better in the traditional education context. Some students believe that online learning helps them develop self-discipline and responsibility, while there are also those who stated that, even though online environment is convenient and comfortable, it made them lazy and lose track of their duties.

Many students think that courses focusing on the development of both perceptive and productive language skills could be more effective when realized in a traditional setting, as, in their opinion, all language skills imply some more personalized type of communication and interaction (including both linguistic and paralinguistic features).

The students' suggestions for a more successful online learning experience, besides the common answers related to the quality of teaching in general (described as well-prepared, well-organized, engaging, creative, implying a variety of materials) include ideas related to a high standard of technical support, which indicates that the demands of a $21^{\text {st }}$ century student have been changed, and to a high degree influence their attitude towards the quality of teaching and learning.

The last question of the survey, formulated as a close-ended Likert 5-point scale question, although restricted as an instrument for a more comprehensive conclusion, with its objective scale expressed in numbers added to the overall positive attitude of the respondents towards their online learning experience.

CONCLUSION

As a result of the COVID-19 pandemic, educational systems have undergone abrupt changes in terms of switching from traditional, face-to-face teaching to an online environment, and this shift hap- 
pened almost overnight, being sudden not only for educational institutions and teachers, but also for students who were not prepared for a newly created learning context beforehand. This study focused on the experience of a group of undergraduate students majoring in English after three successive months of online learning, and draws upon conclusions based on their answers to a survey examining their opinions on different aspects of online learning, and encouraging them to critically reflect upon the quality of the online lectures. The main purpose of this study was to gain a better insight into the characteristics of online teaching and learning, and to pinpoint the areas which need to be improved. However, this study focused on a small group of respondents, which makes the research restricted in its conclusive remarks and final directions of systematic action.

The overall attitude of the respondents towards online teaching and learning experience is rather positive, and the answers to all questions unanimously contribute to this sentiment. However, the results of the research confirm that such mode of learning "represents a naturally evolving process from traditional form of learning to a personalized and focused development path" (Thoren, 2003, p.5), and it offers many possibilities still to be exploited. The insights gained in the research can be taken into consideration while preparing any form of classes meant for generations of students who are digital natives and whose needs and learning habits are changing the educational context, but also for comparison and contrast with similar experiences of learners from the country, region, or some other parts of the world. Still, although the interest in online teaching and learning is growing, the body of evidence related to the online language teaching and learning imposed by the outbreak of Covid-19 is still scarce, and the new insights and comparisons are to be created with new research papers and investigations.

These results of this pilot study can be used as a groundwork for further investigations which could overcome the defects in terms of methodological restrictions and the number of respondents. The direction of a more thorough and detailed study would be to incorporate a more representative research sample including students from different universities studying different languages, as well as a bigger corpus of more questions of both open-ended and close-ended type, so as to avoid repetition of the same or similar answers, and to reach a more comprehensive conclusions. 
REFERENCES Allen, I. E., Seaman, J., Poulin, R., \& Straut, T. T. (2016). Online report card: Tracking online education in the United States. Babson Park: Babson Survey Research Group. Retrieved from http://onlinelearningsurvey.com/reports/ onlinereportcard.pdf.

Castro, R. (2019). Blended learning in higher education: Trends and capabilities. Education and Information Technologies, 24, 2523-2546. doi.org/ 10.1007/s10639-019-09886-3

Ferdig, R.E., Baumgartner, E., Hartshorne, R., Kaplan-Rakowski, R. \& Mouza, C. (Eds). (2020). Teaching, Technology, and Teacher Education During the COVID-19 Pandemic: Stories from the Field. Waynesville, NC: Association for the Advancement of Computing in Education (AACE).

Flecha, R., Pulido, C., Villarejo, B., Racionero, S., Redondo, G. \& Torras, E. (2020). The effects of technology use on children's empathy and attention capacity, NESET Report. Luxembourg: Publications Office of the European Union. doi:10.2766/947826.

Hellerman, J. (2008). Social Actions for Classroom Language Learning. Clevedon: Cromwell Press.

Hockly, N. (2018). Blended Learning. ELT Journal, 72 (1), 97-101. doi.org/ $10.1093 / \mathrm{elt} / \mathrm{ccx} 058$

Hoffman, J. S (2010). Teaching the Humanities Online: A Practical Guide to the Virtual Classroom. London \& New York: Routledge.

Huang, R.H., Liu, D.J., Guo, J., Yang, J.F., Zhao, J.H., Wei, X.F., Knyazeva, S., Li, M., Zhuang, R.X., Looi, C.K., \& Chang, T.W. (2020). Guidance on Flexible Learning during Campus Closures: Ensuring course quality of higher education in COVID-19 outbreak. Beijing: Smart Learning Institute of Beijing Normal University.

Jandrić, P. Postdigital Research in the Time of Covid-19. Postdigital Science and Education, 2, 233-238. https://doi.org/10.1007/s42438-020-00113-8

Killen, R. (2007). Teaching Strategies for Outcomes-Based Education. Juta: Cape Town.

Le Pichon-Vorstman, E., Siarova, H. \& Szőnyi, E. (2020). The future of language education in Europe: case studies of innovative practices, NESET Report. Luxembourg: Publications Office of the European Union. doi.10.2766/81169.

$\mathrm{Pu}, \mathrm{H}$. (2020). Implementing online ELT in the time of crisis: ordeal or opportunity? ELT Journal, ccaa030. doi.org/10.1093/elt/ccaa030

Rapanta, C., Botturi, L., Goodyear, P., Guardia, L. \& Koole, M. (2020). Online University Teaching During and After the Covid-19 Crisis: Refocusing Teacher Presence and Learning Activity. Postdigital Science and Education, 1-23. https://doi.org/10.1007/s42438-020-00155-y.

Sharma P. \& Berrett, B. (2007). Blended Learning. Using Technology in and Beyond the Language Classroom. London: MacMillan. 
Thoren, K. (2003). Blended Learning. How to integrate online and traditional learning. Kogan Page: London.

Yen, S.C., Lo, Y., Lee, A. \& Enriquez, J.M. (2018). Learning online, offline, and in-between: comparing student academic outcomes and course satisfaction in face-to-face, online, and blended teaching modalities. Education and Information Technologies, 23, 2141-2153. doi.org/10.1007/s10639-018-9707-5

ONLINE https://ec.europa.eu/education/news/public-consultation-new-digital-e SOURCES ducation-action-plan_en Retrieved 22 July 2020.

https://unesdoc.unesco.org/ark:/48223/pf0000373348 Retrieved 17 July 2020.

https://read.oecd-ilibrary.org/view/?ref=126_126988-t63lxosohs\&title=A -framework-to-guide-an-education-response-to-the-Covid-19-Pandemicof-2020 Retrieved 28 July 2020.

https://www.schooleducationgateway.eu/downloads/Blended\%20learni ng\%20in\%20school\%20education_European\%20Commission_June\%20202 0.pdf Retrieved 15 July 2020.

МАРИЈАНА М. ПРОДАНОВИТ

ВАЛЕНТИНА М. ГАВРАНОВИТ

УНИВЕРЗИТЕТ СИНГИДУНУМ

СТУДИЈСКИ ПРОГРАМ: АНГЛИСТИКА

САЖЕТАК ОНЛАЈН НАСТАВА: СТАВОВИ СТУДЕНАТА АНГЛИСТИКЕ У ВЕЗИ СА НОВИМ ОБРАЗОВНИМ ОКОЛНОСТИМА НАМЕТНУТИМ ПАНДЕМИЈОМ ВИРУСА КОВИД 19

Иако је примена информационо-комуникационих технологија већ деценијама присутна у настави, у различитим манифестацијама и облицима, тек су се избијањем пандемије ковид 19 у пуном светлу показале предности и могућности које онлајн настава пружа, као и изазови са којима су се образовне институције суочиле. Пандемија је изненада прекинула наставу која се изводила у традиционалном окружењу, а образовне институције широм света су на ову новонасталу ситуацију реаговале на различите начине и са различитим степеном успеха. Европска унија, односно, њена тела су, овим поводом, одмах спровела бројна истраживања која су резултовала низом прописа и препорука којима се креирала нова образовна политика која је постала реалност, и у складу са којом све образовне институције треба да планирају своје будуће кораке и одговоре на дату ситуацију. 
Ова пилот-студија се бави истраживањем карактеристика онлајн наставе кроз призму ставова студената основних студија Англистике, који су последња три месеца академске 2019/2020. године активно учествовали у настави у онлајн окружењу, изненада организованом као одговор на новонасталу пандемијску ситуацију, која је неочекивано прекинула традиционални контекст образовања и преко ноћи променила модел и окружење предавања и наставе. Циљ овог истраживања је да представи податке који се односе на искуство учења студената у онлајн образовном окружењу, као и да пружи бољи увид у природу и карактеристике ове врсте наставе, онако како је виде студенти који раније нису имали слична искуства учења. Спроведено истраживање заснива се на квалитативном методу и обухвата анализу корпуса упитника коју је радила група од 52 студента основних студија. Упитник је највећим делом сачињен од питања отвореног типа у којима се од испитаника тражило да напишу одговоре својим речима, без претходно понуђених опција, чиме је обезбеђен вредан и богат материјал за анализу. Други део упитника чини питање које мери општи став испитаника према квалитету онлајн наставе чији су део били три месеца без прекида и за које је коришћена Ликертова скала процене. Одговори студената су анализирани и класификовани у неколико категорија према својеврсном заједничком именитељу. Резултати истраживања указују на мишљења студената у вези са неколико аспеката онлајн наставе: предности и недостаци, поређење са традиционалним образовним окружењем, предмети који су погоднији да се изводе у традиционалном, односно онлајн окружењу. Студенти у одговорима наводе и аспекте онлајн наставе које сматрају приоритетним, али, такође, и предлоге како се тај облик наставе може унапредити. Резултати истраживања не само да истичу предности и мане онлајн наставе већ указују и на различите аспекте и сложену природу наставе уопште, у којој социолошки и психолошки фактори имају веома важну улогу.

КљУчнЕ РЕчи: учење језика у онлајн окружењу; пандемија ковид 19; ставови студената англистике.

Овај чланак је објављен и дистрибуира се под лиценцом Creative Commons Ауторство-Некомерцијално Међународна 4.0 (СC BY-NC 4.0 |

https://creativecommons.org/licenses/by-nc/4.0/).

This paper is published and distributed under the terms and conditions of the Creative Commons Attribution-NonCommercial International 4.0 licence (CC BY-NC 4.0 | https://creativecommons.org/licenses/by-nc/4.0/). 